\title{
DNA repair gene ERCC2 polymorphisms and associations with breast and ovarian cancer risk
}

\author{
Dominique Bernard-Gallon ${ }^{1,2}$, Rémy Bosviel ${ }^{1,2}$, Laetitia Delort ${ }^{1,2}$, \\ Luc Fontana ${ }^{3,4}$, Alain Chamoux ${ }^{3,4}$, Nadège Rabiau1,2, Fabrice Kwiatkowski1,2, \\ Nasséra Chalabi1,2, Samir Satih ${ }^{1,2}$ and Yves-Jean Bignon*1,2,3
}

\begin{abstract}
Address: ${ }^{1}$ Département d'Oncogénétique du Centre Jean Perrin, EA 2416 CBRV, 28 Place Henri Dunant, B.P. 38 , 63001 Clermont-Ferrand Cedex 01, France, ${ }^{2} \mathrm{CRNH}, 58$ rue Montalembert, 63009 Clermont-Ferrand Cedex 01, France, ${ }^{3}$ Univ Clermont 1, UFR Médecine, Institut de Médecine du Travail, 28 place Henri Dunant, 63001 Clermont-Ferrand, France and ${ }^{4} \mathrm{CHU}$ Clermont-Ferrand, Service Santé Travail Environnement, 28 place Henri Dunant, 63001 Clermont-Ferrand cedex, France

Email: Dominique Bernard-Gallon - Dominique.Bernard-Gallon@cjp.fr; Rémy Bosviel - remy.bosviel@caramail.com; Laetitia Delort - delort.laetitia@neuf.fr; Luc Fontana - Luc.Fontana@u-clermont1.fr; Alain Chamoux - Alain.Chamoux@u-clermont1.fr; Nadège Rabiau - rabiau@soluscience.fr; Fabrice Kwiatkowski - Fabrice.KWIATKOWSKI@cjp.fr; Nasséra Chalabi - chalabi.nassera@wanadoo.fr; Samir Satih - samir.satih@caramail.com; Yves-Jean Bignon* - Yves-Jean.Bignon@cjp.fr

* Corresponding author
\end{abstract}

Published: 2 May 2008

Molecular Cancer 2008, 7:36 doi:10.1186/1476-4598-7-36
Received: 14 November 2007

Accepted: 2 May 2008

This article is available from: http://www.molecular-cancer.com/content/7/1/36

(c) 2008 Bernard-Gallon et al; licensee BioMed Central Ltd.

This is an Open Access article distributed under the terms of the Creative Commons Attribution License (http://creativecommons.org/licenses/by/2.0), which permits unrestricted use, distribution, and reproduction in any medium, provided the original work is properly cited.

\begin{abstract}
Breast and ovarian cancers increased in the last decades. Except rare cases with a genetic predisposition and high penetrance, these pathologies are viewed as a polygenic disease. In this concept, association studies look for genetic variations such as polymorphisms in low penetrance genes, i.e. genes in interaction with environmental factors. DNA repair systems that protect the genome from deleterious endogenous and exogenous damages have been shown to have significantly reduced. In particular, enzymes of the nucleotide excision repair pathway are suspected to be implicated in cancer. In this study, 2 functional polymorphisms in a DNA repair gene ERCC2 were analyzed. The population included $91 \mathrm{I}$ breast cancer cases, 51 ovarian cancer cases and 1000 controls. The genotyping of 2 SNP (Single Nucleotide Polymorphism) was carried out on the population with the MGB (Minor Groove Binder) probe technique which consists of the use of the allelic discrimination with the Taqman ${ }^{\circledR}$ method. This study enabled us to show an increase in risk of breast cancer with no oral contraceptive users and with women exhibiting a waist-to-hip ratio (WHR) > 0.85 for Asn homozygous for ERCC2 $3 / 2$.
\end{abstract}

\section{Background}

High levels of DNA damage, caused by excessive exposure to carcinogens, might be responsible for increased breast cancer susceptibility in women known to have significantly reduced DNA repair proficiencies [1]. In particular, dysfunctions of the nucleotide excision repair (NER) pathway are known or suspected to be involved in cancer. The DNA helicase encoded by the excision repair cross- complementing group 2 gene ERCC2 (formely XPD) is one of seven nucleotide excision repair enzymes that cause Xeroderma Pigmentosum when mutated in germ line [2]. Several polymorphisms have been identified in this gene and particularly the Asp312Asn ERCC2 polymorphism which consists of the substitution of a $G$ to A resulting in an amino acid change in the coding region, and the Lys751Gln which consists in a A to C substitution in the 
coding region [3]. A change of amino acid is able to modify the effect of protein more or less, which can translate by an effect on the systems of repair and consequently on the carcinogenesis. Conflicting data on the roles of these polymorphisms on cancer risk including breast and ovarian cancers have been described [4-6].

The objective of this study was to establish the role of two functional polymorphisms of a DNA repair gene ERCC2 in the risk of breast or ovarian cancer. We investigated the possible interactions between these polymorphisms and specific environmental factors (reproductive factors, body mass index, tobacco smoking...) which could influence the risk of cancer.

\section{Results}

Risk associated with individual SNPs

In this breast cancer population (Table 1), no significant differences were found between breast cancer cases and controls. A trend to the increase in breast cancer risk could be observed with heterozygous women for the SNP at position 312 of ERCC2 protein $(\mathrm{OR}=1.06 ; 95 \% \mathrm{CI}=$ 0.93-1.21) after adjustment for age. For ovarian cancer (Table 2), there was no significant modification in the risk for the two studied SNP.

\section{Interaction between genetic factors and anthropometricl lifestyle factors}

Results concerning interactions between environmental factors and risk of breast cancer were reported in Table 3 . Nonsmoker homozygous Asn at position 312 of ERCC2 tended towards an increase in the risk of developing breast cancer $(\mathrm{OR}=1.4 ; 95 \% \mathrm{CI}=0.98-2.02)$. Heterozygous individuals for ERCC2 Asp312Asn which received a hormonal replacement therapy (HRT) exhibited a risk to develop breast cancer $(\mathrm{OR}=1.39 ; 95 \% \mathrm{CI}=0.97-1.99)$. A significant increase in the risk was observed for individuals who did not take oral contraceptives and who were homozygous Asn at position 312 of ERCC2 (OR = 1.66; $95 \% \mathrm{CI}=1.08-2.53)$. An increase was observed for heterozygous individuals at position 751 of ERCC2 who took oral contraceptives $(\mathrm{OR}=1.54 ; 95 \% \mathrm{CI}=1.00-2.36)$.
When age at first oral contraceptive use was after 23 years, a significant increase in breast cancer risk was obtained for heterozygous ERCC2 Lys751Gln $(\mathrm{OR}=2.22 ; 95 \% \mathrm{CI}=$ 1.15-4.29). Lastly, women with a waist-to-hip ratio (WHR) > 0.85 and homozygous for position 312 of ERCC2 exhibited a significant increase in the risk of breast cancer $(\mathrm{OR}=1.96 ; 95 \% \mathrm{CI}=1.12-3.43)$.

Concerning ovarian cancer (Table 4), a significant increase in the risk was found for heterozygous ERCC2 Lys751Gln and who had menarche before 13 years old $(\mathrm{OR}=6.03 ; 95 \% \mathrm{CI}=1.02-35.78)$. Heterozygous individuals ERCC2 Asp312Asn who did not take oral contraceptives had a significant increase in the risk of ovarian cancer $(\mathrm{OR}=2.16 ; 95 \% \mathrm{CI}=1.08-4.33)$. Heterozygous ERCC2 Asp312Asn with BMI $>25$ exhibited a significant increase in ovarian cancer risk $(\mathrm{OR}=3.5 ; 95 \% \mathrm{CI}=1.00-12.26)$, while heterozygous ERCC2 Lys751Gln with body mass index (BMI) $<25$ exhibited an upward tendency in ovarian cancer risk $(\mathrm{OR}=5.64 ; 95 \% \mathrm{CI}=0.93-33.99)$. Heterozygous ERCC2 Lys751Gln with WHR $=0.85$ also exhibited an upward tendency in the risk of ovarian cancer $(\mathrm{OR}=5.68 ; 95 \% \mathrm{CI}=0.94-34.25)$.

\section{Discussion}

Nucleotide Excision Repair (NER) pathway is a key DNA repair system. A dysfunction of this system would result in higher cancer susceptibility because individuals would be more exposed to carcinogens. Exogenous (cigarette smoke, pollutants) and endogenous carcinogens are potential breast and ovarian cancer risk factors. Above all, exposition to estrogens seemed to be the major risk factor. Indeed, estrogens had proliferative effects on mammary cells and could be metabolized in potential carcinogens and induce DNA damage [7]. Many investigations were done concerning breast cancer risk and DNA repair polymorphisms. At the opposite, few studies were done with ovarian cancer which exhibited a lower incidence but a high mortality rate. So we studied two polymorphisms in ERCC2 DNA repair gene because these polymorphisms might modify the exposure of women to estrogens.

Table I: ERCC2 Asp3 I 2Asn and ERCC2 Lys75 I Gln polymorphisms and breast cancer risk

\begin{tabular}{|c|c|c|c|c|c|}
\hline Genotype & Cases (\%) & Controls (\%) & OR (95\%Cl) & ORadj* (95\%Cl) & $P$ value \\
\hline \multicolumn{6}{|l|}{ ERCC2 Asp312Asn } \\
\hline Asp/Asp & $403(45)$ & $458(46)$ & 1.00 (reference) & 1.00 (reference) & \\
\hline Asp/Asn & $383(42)$ & $418(42)$ & $1.04(0.86-1.26)$ & $1.06(0.93-1.21)$ & \\
\hline Asn/Asn & $118(13)$ & $118(12)$ & $1.14(0.85-1.52)$ & $1.12(0.86-1.46)$ & 0.68 \\
\hline \multicolumn{6}{|l|}{ ERCC2 Lys75I Gln } \\
\hline Lys/Lys & $121(13)$ & $119(11)$ & I.00 (reference) & 1.00 & \\
\hline Lys/Gln & $419(46)$ & $446(44)$ & $0.92(0.69-1.23)$ & $0.92(0.80-1.05)$ & \\
\hline Gln/Gln & $368(40)$ & $430(43)$ & $0.84(0.63-1.12)$ & $0.84(0.64-1.09)$ & 0.43 \\
\hline
\end{tabular}

* Adjusted for age 
Table 2: ERCC2 Asp3 I 2Asn and ERCC2 Lys75 IGIn polymorphisms and ovarian cancer risk

\begin{tabular}{|c|c|c|c|c|c|}
\hline Genotype & Cases (\%) & Controls (\%) & OR (95\%Cl) & ORadj* (95\%Cl) & $P$ value \\
\hline \multicolumn{6}{|l|}{ ERCC2 Asp312Asn } \\
\hline Asp/Asp & $2 I(4 I)$ & $458(46)$ & I.00 (reference) & I.00 (reference) & \\
\hline Asp/Asn & $28(55)$ & $418(42)$ & $1.46(0.82-2.60)$ & $0.95(0.62-1.45)$ & \\
\hline Asn/Asn & $2(4)$ & $118(12)$ & $0.37(0.09-1.51)$ & $0.9(0.39-2.12)$ & 0.088 \\
\hline \multicolumn{6}{|l|}{ ERCC2 Lys75IGln } \\
\hline Lys/Lys & I (2) & $119(12)$ & I.00 (reference) & 1.00 (reference) & \\
\hline Lys/Gln & $31(61)$ & $446(45)$ & $8.27(1.54-44.43)$ & $1.08(0.70-1.66)$ & \\
\hline$G \ln / G \ln$ & $19(37)$ & $430(43)$ & $5.26(0.86-32.18)$ & $1.16(0.49-2.75)$ & 0.025 \\
\hline
\end{tabular}

* Adjusted for age

An early age at menarche increases the risk of ovarian and breast cancers, probably due to the prolonged exposure of breast epithelium to endogenous hormones. Similarly a late age at menopause is considered as a risk for cancer because it increases the number of ovulatory cycles [8]. Concerning parity, a dual effect of pregnancy is reported. On one hand, parity inhibits the early stages of mammary carcinogenesis (long-term risk reduction) due to the terminal differentiation of breast tissue. On the other hand, there is a short-term risk increase because of the proliferation of breast tissue in response to high gestational hormone levels which render the mammary gland more susceptible to carcinogens [9]. Overall early pregnancy and high parity are considered to have a protective effect [10-13].

Oral contraceptive use was by far the most influential factor on breast cancer development. However, the hormonal replacement therapy generates a prolonged exposure to estrogens during life, leading to an increased risk of breast and ovarian cancers. At the opposite, the established protective effect of OC use in ovarian cancer may also be due to the suppression of the LH peak and to a decrease of endogenous estradiol production. If estrogens are related to an increased risk of ovarian cancer, oral contraception might have some protective effect by lowering the overall level of estrogens $[14,15]$.

Studies of the relationship between BMI and the risk of ovarian cancer have been inconclusive, finding either a positive correlation [16-23], no relationship [24-31], or negative association [32]. Our results suggested an interaction with menopausal status, with higher BMI being more associated with ovarian cancer risk in premenopausal women than in postmenopausal women, in agreement with Beehler et al (2006) [33]. Greer et al (2005) showed a slight increase in risk with weight during adulthood and later in life, which was most apparent among nulliparous women [34]. Fairfield et al (2002) did not find any association between recent BMI and risk of ovarian cancer, but reported that a high BMI during early adulthood was asso- ciated with an increased risk of premenopausal cancer [26]. A case-control study reported an association between increased BMI at age 18 and during most adult life and ovarian cancer [23].

We found a strong relationship between waist-to-hip ratio and the risk of ovarian cancer regardless of menopausal status, underscoring the role of central adiposity in the induction of ovarian cancer [35].

In addition, we studied tobacco smoking, the role of which was very important in ovarian and breast cancers. For ovarian and breast cancers, the role of the tobacco is complex. Some of cigaret smoke compounds will have an anti-estrogen effect, while others such as HAP, AAH and $\mathrm{N}$-nitrosamines will act as carcinogens by acting directly on DNA. The lipophilic HAP are stored in fat tissues, which include the mammary glands and tissues surrounding the ovaries [7].

Our results showed an increase in the risk of breast cancer in individual heterozygous for ERCC2 Asp312Asn with women receiving a menopause substitutive treatment and an increased risk for ovarian cancer with no oral contraceptive uses, and/or BMI > 25. For heterozygous ERCC2 Lys $751 \mathrm{Gln}$, an increased risk for breast cancer was found with age at first OC use after 23 years. Heterozygous ERCC2 Lys751Gln exhibited a higher risk for ovarian cancer when age at menarche was before 13 years, $\mathrm{BMI}<25$ and WHR $<0.85$.

Besides, homozygous Asn for ERCC2 312 tended to have an increase in breast cancer risk among nonsmokers, and a significant increase in breast cancer risk among OC users or with WHR $>0.85$. It might be a combined effect between DNA damage caused by estrogens and reduced DNA repair proficiency with ERCC2. For the other first results, the explanation might be a reduced DNA repair proficiency with ERCC2 but it was found when the interaction between genetic factors and anthropometric/lifestyle factors was considered. 
Table 3: ERCC2 Asp3 I 2Asn, ERCC2 Lys75 I GIn polymorphisms and potential breast cancer risk factors

\begin{tabular}{|c|c|c|c|c|c|c|c|c|}
\hline \multirow[b]{2}{*}{ Genotype } & \multicolumn{4}{|c|}{ Nonsmokers } & \multicolumn{4}{|c|}{ Smokers } \\
\hline & Cases (\%) & Controls (\%) & OR (Cl 95\%) & $P$ value & Cases (\%) & Controls (\%) & OR (Cl 95\%) & $P$ value \\
\hline \multicolumn{9}{|l|}{ ERCC2 Asp3 I 2Asn } \\
\hline Asp/Asp & $283(45)$ & $299(47)$ & 1.00 (reference) & & $102(42)$ & $159(44)$ & $\mathrm{I} .00$ (reference) & \\
\hline Asp/Asn & $258(4 I)$ & $270(43)$ & $1.01(0.80-1.28)$ & & III (46) & $146(4 \mid)$ & $1.19(0.83-1.68)$ & \\
\hline Asn/Asn & $85(14)$ & $64(10)$ & $1.4(0.98-2.02)$ & 0.16 & $29(12)$ & $54(15)$ & $0.84(0.50-1.40)$ & 0.36 \\
\hline & \multicolumn{4}{|c|}{ No HRT* users } & \multicolumn{4}{|c|}{ HRT users } \\
\hline Genotype & Cases (\%) & Controls (\%) & OR (Cl 95\%) & $P$ value & Cases (\%) & Controls (\%) & OR (Cl 95\%) & $P$ value \\
\hline \multicolumn{9}{|l|}{ ERCC2 Asp3/2Asn } \\
\hline Asp/Asp & $175(46)$ & 137 (48) & 1.00 (reference) & & $75(40)$ & $216(47)$ & $\mathrm{I} .00$ (reference) & \\
\hline Asp/Asn & $152(40)$ & $119(4 I)$ & $1.00(0.72-1.39)$ & & $92(49)$ & $191(42)$ & $1.39(0.97-1.99)$ & \\
\hline Asn/Asn & $54(14)$ & $3 I(I I)$ & $1.36(0.83-2.23)$ & 0.44 & $19(10)$ & $50(\mathrm{II})$ & $1.09(0.6 \mathrm{I}-1.97)$ & 0.20 \\
\hline & \multicolumn{4}{|c|}{ No OC** users } & \multicolumn{4}{|c|}{ OC users } \\
\hline Genotype & Cases (\%) & Controls (\%) & OR (Cl 95\%) & $P$ value & Cases (\%) & Controls (\%) & OR (Cl 95\%) & $P$ value \\
\hline \multicolumn{9}{|l|}{ ERCC2 Asp3 I 2Asn } \\
\hline Asp/Asp & $240(46)$ & $215(50)$ & I.00 (reference) & & 143 (42) & $243(43)$ & 1.00 (reference) & \\
\hline Asp/Asn & $208(40)$ & $176(4 \mid)$ & $1.06(0.8 \mathrm{I}-1.39)$ & & 161 (47) & $242(43)$ & I.I3 (0.85-I.5I) & \\
\hline Asn/Asn & $74(14)$ & $40(9)$ & $1.66(1.08-2.53)$ & 0.061 & $40(12)$ & $78(14)$ & $0.87(0.56-1.34)$ & 0.44 \\
\hline \multicolumn{9}{|l|}{ ERCC2 Lys75/Gln } \\
\hline Lys/Lys & $79(15)$ & $39(9)$ & I.00 (reference) & & $38(\mathrm{II})$ & $80(14)$ & 1.00 (reference) & \\
\hline Lys/Gln & $223(43)$ & $198(46)$ & $0.56(0.36-0.85)$ & & $181(52)$ & $248(44)$ & $1.54(1.00-2.36)$ & \\
\hline \multirow[t]{2}{*}{$G \ln / G \ln$} & $222(42)$ & $195(45)$ & $0.56(0.37-0.86)$ & 0.018 & $127(37)$ & $235(42)$ & $1.14(0.73-1.77)$ & 0.044 \\
\hline & \multicolumn{4}{|c|}{ Age at first $O C$ use $\leq 23$ years } & \multicolumn{4}{|c|}{ Age at first $O C>23$ years } \\
\hline Genotype & Cases (\%) & Controls (\%) & OR (Cl 95\%) & $P$ value & Cases (\%) & Controls (\%) & OR (Cl 95\%) & $P$ value \\
\hline \multicolumn{9}{|l|}{ ERCC2 Lys75/Gln } \\
\hline Lys/Lys & $23(14)$ & $46(15)$ & 1.00 (reference) & & $15(8)$ & $34(13)$ & 1.00 (reference) & \\
\hline Lys/Gln & $80(50)$ & 145 (47) & $1.10(0.62-1.95)$ & & $101(55)$ & $103(40)$ & $2.22(1.15-4.29)$ & \\
\hline \multirow[t]{2}{*}{ Gln/Gln } & $58(36)$ & $115(38)$ & $1.01(0.56-1.82)$ & 0.89 & $69(37)$ & $120(47)$ & $1.3(0.66-2.56)$ & 0.008 \\
\hline & \multicolumn{4}{|c|}{ Waist-to-hip ratio $=0.85$} & \multicolumn{4}{|c|}{ Waist-to-hip ratio $>0.85$} \\
\hline Genotype & Cases (\%) & Controls (\%) & OR ( $\mathrm{Cl} 95 \%)$ & $P$ value & Cases (\%) & Controls (\%) & OR (Cl 95\%) & $P$ value \\
\hline \multicolumn{9}{|l|}{ ERCC2 Asp3/2Asn } \\
\hline Asp/Asp & $252(46)$ & $356(46)$ & I.00 (reference) & & $|5|(42)$ & $102(48)$ & 1.00 (reference) & \\
\hline Asp/Asn & $234(43)$ & $326(42)$ & $1.01(0.80-1.28)$ & & $149(42)$ & $92(43)$ & $1.09(0.76-1.57)$ & \\
\hline Asn/Asn & 60 (II) & $98(13)$ & $0.86(0.60-1.24)$ & 0.68 & $58(16)$ & $20(9)$ & $1.96(1.12-3.43)$ & 0.06 \\
\hline
\end{tabular}

* HRT $=$ Hormone Replacement Therapy

$* *$ OC $=$ Oral Contraceptive

Contradictory results were found in the literature. Tang et al (2002) did not show an association between these two SNP in ERCC2 and breast cancer risk whereas a lower A allele frequency in ERCC2 Asp312Asn was found in a Chinese population by Zhang et al $(2005)[5,36]$. On the contrary, a case-control study in Portugal revealed that women with the Asn312Asn or the Gln751Gln genotype presented a three-fold risk of ovarian cancer in comparison with heterozygous or wild-type homozygous women [3]. 
Table 4: ERCC2 Asp3 I 2Asn, ERCC2 Lys75 I Gln polymorphisms and potential ovarian cancer risk factors

\begin{tabular}{|c|c|c|c|c|c|c|c|c|}
\hline \multirow[b]{2}{*}{ Genotype } & \multicolumn{4}{|c|}{ Age at menarche $=13$ years } & \multicolumn{4}{|c|}{ Age at menarche $>13$ years } \\
\hline & Cases (\%) & Controls (\%) & OR (Cl 95\%) & $P$ value & Cases (\%) & Controls (\%) & OR (Cl 95\%) & $P$ value \\
\hline \multicolumn{9}{|l|}{ ERCC2 Lys75IGln } \\
\hline Lys/Lys & I (3) & $87(13)$ & 1.00 (reference) & & $0(0)$ & $32(10)$ & - & \\
\hline Lys/Gln & $21(57)$ & $303(46)$ & $6.03(1.02-35.78)$ & & $10(7 I)$ & $175(52)$ & 1.00 (reference) & \\
\hline$G \ln / G \ln$ & $15(4 I)$ & $27 I(4 I)$ & $4.82(0.6-30.62)$ & 0.14 & $4(29)$ & $127(38)$ & $0.55(0.17-1.77)$ & 0.32 \\
\hline & \multicolumn{4}{|c|}{ No OC* users } & \multicolumn{4}{|c|}{ OC users } \\
\hline Genotype & Cases (\%) & Controls (\%) & OR (Cl 95\%) & & Cases (\%) & Controls (\%) & OR (Cl 95\%) & \\
\hline \multicolumn{9}{|l|}{ ERCC2 Asp3 I 2Asn } \\
\hline Asp/Asp & $13(35)$ & $215(50)$ & 1.00 (reference) & & $5(50)$ & $243(43)$ & 1.00 (reference) & \\
\hline Asp/Asn & $23(62)$ & I76 (4I) & $2.16(1.08-4.33)$ & & $5(50)$ & $242(43)$ & $1.00(0.29-3.51)$ & \\
\hline Asn/Asn & I (3) & $40(9)$ & $0.41(0.06-3.05)$ & 0.032 & $0(0)$ & $78(14)$ & - & 0.45 \\
\hline \multicolumn{9}{|l|}{ ERCC2 Lys 75 I Gln } \\
\hline Lys/Lys & $0(0)$ & $39(9)$ & - & & $0(0)$ & $80(14)$ & - & \\
\hline Lys/Gln & $27(73)$ & $198(46)$ & 1.00 (reference) & & $4(40)$ & $248(44)$ & 1.00 (reference) & \\
\hline$G \ln / G \ln$ & $10(27)$ & $195(45)$ & $0.38(0.18-0.78)$ & 0.0085 & $6(60)$ & $235(42)$ & $1.58(0.45-5.62)$ & $0.7^{* *}$ \\
\hline & \multicolumn{4}{|c|}{ BMI $\leq \mathbf{2 5}$} & \multicolumn{4}{|c|}{ BMI >25 } \\
\hline Genotype & Cases (\%) & Controls (\%) & OR (Cl 95\%) & & Cases (\%) & Controls (\%) & OR (Cl 95\%) & \\
\hline \multicolumn{9}{|l|}{ ERCC2 Asp3 I 2Asn } \\
\hline Asp/Asp & $18(47)$ & $311(45)$ & 1.00 (reference) & & $3(23)$ & I47 (48) & 1.00 (reference) & \\
\hline Asp/Asn & $19(50)$ & $292(43)$ & $1.12(0.58-2.18)$ & & $9(69)$ & $126(4 I)$ & $3.5(1.00-12.26)$ & \\
\hline Asn/Asn & I (3) & $84(12)$ & $0.21(0.03-1.29)$ & 0.19 & I (8) & $34(\mathrm{II})$ & $1.44(0.15-14.11)$ & 0.13 \\
\hline \multicolumn{9}{|l|}{ ERCC2 Lys 75 I Gln } \\
\hline Lys/Lys & I (3) & $84(12)$ & 1.00 (reference) & & $0(0)$ & $35(\mathrm{II})$ & - & \\
\hline Lys/Gln & $21(55)$ & $313(45)$ & $5.64(0.93-33.99)$ & & $10(77)$ & $133(43)$ & 1.00 (reference) & \\
\hline$G \ln / G \ln$ & $16(42)$ & 291 (42) & $4.62(0.72-29.53)$ & 0.17 & $3(23)$ & $139(45)$ & $0.290 .08-0.99)$ & 0.048 \\
\hline & \multicolumn{4}{|c|}{ Waist-to-hip ratio $=0.85$} & \multicolumn{4}{|c|}{ Waist-to-hip ratio $>0.85$} \\
\hline Genotype & Cases (\%) & Controls (\%) & OR (Cl 95\%) & & Cases (\%) & Controls (\%) & OR (Cl 95\%) & \\
\hline \multicolumn{9}{|l|}{ ERCC2 Lys75/Gln } \\
\hline Lys/Lys & I (4) & $102(13)$ & 1.00 (reference) & & $0(0)$ & $17(8)$ & - & \\
\hline Lys/Gln & $19(70)$ & $34 I(44)$ & $5.68(0.94-34.25)$ & & $12(50)$ & $105(49)$ & 1.00 (reference) & \\
\hline$G \ln / G \ln$ & $7(26)$ & $338(43)$ & $2.11(0.27-16.57)$ & 0.02 & $12(50)$ & $92(43)$ & $1.14(0.49-2.66)$ & 0.76 \\
\hline
\end{tabular}

\section{Conclusion}

This study enabled us to show an increase in risk of breast cancer with no oral contraceptive users and with women exhibiting a waist-to-hip ratio superior to 0.85 for Asn homozygous for ERCC2 312.

\section{Subjects and Methods \\ Study Subjects}

911 breast cancer cases and 51 ovarian cancer cases (aged 26-89 years), from the Auvergne region in France were included. They are belonging to the COSA program (Breast and Ovarian Cancer in the Auvergne region) that consisted of the recruitment of identified women from different clinics and hospitals in the Auvergne region in France from November 1996 through November 1999. 
Table 5: Two functional polymorphisms were studied in a DNA repair gene (ERCC2)

\begin{tabular}{cccc}
\hline Gene Symbols & Names & Studied Polymorphisms (SNP) & Polymorphism NCBI References \\
\hline ERCC2IXPD & $\begin{array}{c}\text { Excision Repair Cross-Complementing group 2 } \\
\text { Xeroderma Pigmentosum group D }\end{array}$ & $\begin{array}{l}\text { Asp3I2Asn [G2359IA (exon 10)] } \\
\text { Lys75I Gln [A3593IC (exon 23)] }\end{array}$ & $\begin{array}{c}\text { rsI799793 } \\
\text { rsI3I8I }\end{array}$ \\
\hline
\end{tabular}

Eligible subjects were women who had been diagnosed with breast or ovarian cancer with no BRCA mutation and no more than one first degree relative breast cancer.

1,000 healthy control women (aged 24-85 years) were recruited in a mammographic screening center from July 2005 to April 2006. Eligible controls were women with no previous history of cancer and resident in the Auvergne region. All study subjects received counseling and provided written consent for the study.

\section{Data collection}

Participants completed a questionnaire about their medical and reproductive histories in particular. Breast and ovarian cases filled in the questionnaire at the time of clinic appointment whereas controls were interviewed at the medical center at the time of enrollment. Data regarding reproductive history (including gravidity, parity, age at first-full term pregnancy, history of breastfeeding, age at menarche and menopause, menstrual cycle regularity, hormone replacement therapy), use of oral contraceptives (OC) ("Ever use" of OC was defined as at least 3 months of use), age at first OC use and duration of OC, anthropometric characteristics (height, weight, weight at age 20, waist and hip measurements), smoking status ("ever smoker" was defined as at least 1 year of smoking) were collected.

\section{Genotyping}

For breast and ovarian cancer patients and healthy women, genomic DNAs were extracted from whole blood using DNA extraction kit by Euromedex according to the manufacturer's protocol (Euromedex, Souffelweyersheim, France). Two functional polymorphisms of a DNA repair gene ERCC2 were selected (Table 5). The corresponding probes were ordered at the company Applied Biosystems. Allelic discrimination using fluorogenic probes ( 5 ' nuclease assay, Taqman ${ }^{\varpi}$ ) was chosen for genotyping on the ABI PRISM 7700 Sequence Detection Systems (Applied Biosystems, Foster City, CA, USA) and consisted of the use of allele-specific fluorogenic probes [37]. Sixteen nanograms of DNA were amplified by AmpliTaq Gold DNA polymerase which was included in Taqman ${ }^{\circledast}$ Universal Master Mix (Applied Biosystems, Foster City, CA, USA). The PCR reactions were as follows: one step of $10 \mathrm{~min}$ at $95^{\circ} \mathrm{C}$ followed by 40 cycles of two-step PCR with denaturation at $92^{\circ} \mathrm{C}$ for $15 \mathrm{~s}$ and annealing and extension at $60^{\circ} \mathrm{C}$ for 1 min. Ten percent of all samples were genotyped again for quality control.

\section{Statistical Analysis}

The software SEM (Centre Jean Perrin, Clermont Ferrand, France) was used for data analyses [38]. Standard descriptive statistics consisted in means plus standard deviation for quantitative data. Comparisons between cases and controls were performed using $\mathrm{Chi}^{2}$-squared test for qualitative parameters. Univariate and multivariate analyses were performed to determine cancer risk factors in our populations, and odds ratios (ORs) with corresponding $95 \%$ confidence interval (95\% CI) were estimated.

Allelic frequencies and the distribution of genotype were compared within the two populations using $\mathrm{Chi}^{2}$ analysis and ORs with $95 \%$ CI. Yates correction was performed when the number of cases was inferior to 5 . The potential confounding effects of known breast cancer risk factors (age at menarche, number of children, age at first child birth, menopause, breastfeeding, oral contraceptive (OC) use, age at first OC use, body mass index [BMI], BMI at 20 years old, waist-to-hip ratio [WHR] and smoking) were evaluated by adjusting for unconditional logistic regression and calculation of ORs. As no changes in ORs were noted, results were reported without adjustment for these factors.

\section{Competing interests}

The authors declare that they have no competing interests.

\section{Authors' contributions}

DBG, LD was responsible for genotyping polymorphisms, statistical analyses and interpretation, and drafting of the manuscript; RB, NC, SS, NR contributed with the coordination of the study and helped in statistical analyses; FK provided expertise in data analyses; YJB, DBG, LF, AC contributed to the study design and manuscript preparation. All authors participated in the preparation of the manuscript and approved the final version.

\section{Acknowledgements}

This study was supported by "La Ligue Nationale Française de Lutte Contre le Cancer" (Puy-de-Dôme, Allier and Cantal). Laetitia Delort is a recipient of a grant from the "Association pour la Recherche sur le Cancer", Villejuif, France. Nasséra Chalabi is a post-graduate of the CLARA "Cancéropôle Lyon-Auvergne-Rhône-Alpes", France. N. Rabiau is a recipient of a grant "CIFRE" from Soluscience S.A., Clermont-Ferrand, France. The authors 
wish to thank Centre République, Clermont Ferrand, France, for the enrollment of control population.

\section{References}

I. Helzlsouer KJ, Harris EL, Parshad R, Perry HR, Price FM, Sanford KK: DNA repair proficiency: potential susceptiblity factor for breast cancer. J Natl Cancer Inst 1996, 88:754-755.

2. Coin F, Marinoni JC, Rodolfo C, Fribourg S, Pedrini AM, Egly JM: Mutations in the XPD helicase gene result in XP and TTD phenotypes, preventing interaction between XPD and the p44 subunit of TFIIH. Nat Genet I998, 20: |84- I88.

3. Costa S, Pinto D, Pereira D, Vasconcelos A, Afonso-Lopes C, Osorio T, Lopes C, Medeiros R: Importance of xeroderma pigmentosum group $D$ polymorphisms in susceptibility to ovarian cancer. Cancer Lett 2007, 246:324-330.

4. Lunn RM, Helzlsouer KJ, Parshad R, Umbach DM, Harris EL, Sanford KK, Bell DA: XPD polymorphisms: effects on DNA repair proficiency. Carcinogenesis 2000, 2 I:55I-555.

5. Tang D, Cho S, Rundle A, Chen S, Phillips D, Zhou J, Hsu Y, Schnabel F, Estabrook A, Perera FP: Polymorphisms in the DNA repair enzyme XPD are associated with increased levels of PAHDNA adducts in a case-control study of breast cancer. Breast Cancer Res Treat 2002, 75:159-166.

6. Justenhoven C, Hamann U, Pesch B, Harth V, Rabstein S, Baisch C, Vollmert C, Illig T, Ko YD, Bruning T, Brauch H: ERCC2 genotypes and a corresponding haplotype are linked with breast cancer risk in a German population. Cancer Epidemiol Biomarkers Prev 2004, I 3:2059-2064.

7. Mitrunen K, Hirvonen A: Molecular epidemiology of sporadic breast cancer. The role of polymorphic genes involved in oestrogen biosynthesis and metabolism. Mutat Res 2003, 544:9-4I.

8. Dumitrescu RG, Cotarla I: Understanding breast cancer risk -where do we stand in 2005? J Cell Mol Med 2005, 9:208-22I.

9. Bernard-Gallon DJ, De Latour MP, Sylvain V, Vissac C, Aunoble B, Chassagne J, Bignon YJ: Brca I and Brca2 protein expression patterns in different tissues of murine origin. Int J Oncol 200I, I 8:27|-280.

10. Dumitrescu RG, Cotarla I: Understanding breast cancer risk where do we stand in 2005? J Cell Mol Med 2005, 9:208-22I.

II. Innes KE, Byers TE: First pregnancy characteristics and subsequent breast cancer risk among young women. Int J Cancer 2004, I I 2:306-3 I I.

12. Pathak DR: Dual effect of first full term pregnancy on breast cancer risk: empirical evidence and postulated underlying biology. Cancer Causes Control 2002, 13:295-298.

13. Russo J, Russo IH: Cellular basis of breast cancer susceptibility. Oncol Res 1999, I I:169-178.

14. Killick S, Eyong E, Elstein M: Ovarian follicular development in oral contraceptive cycles. Fertil Steril 1987, 48:409-4I3.

15. Pelucchi C, Galeone C, Talamini R, Bosetti C, Montella M, Negri E, Franceschi S, La Vecchia C: Lifetime ovulatory cycles and ovarian cancer risk in 2 Italian case-control studies. Am J Obstet Gynecol 2007, I96(I):83 el-7.

16. Rodriguez C, Calle EE, Fakhrabadi-Shokoohi D, Jacobs EJ, Thun MJ: Body mass index, height, and the risk of ovarian cancer mortality in a prospective cohort of postmenopausal women. Cancer Epidemiol Biomarkers Prev 2002, I I :822-828.

17. Schouten LJ, Goldbohm RA, van den Brandt PA: Height, weight, weight change, and ovarian cancer risk in the Netherlands cohort study on diet and cancer. Am J Epidemiol 2003, I 57:424-433.

18. Hirose K, Tajima K, Hamajima N, Kuroishi T, Kuzuya K, Miura S, Tokudome S: Comparative case-referent study of risk factors among hormone-related female cancers in Japan. Jpn J Cancer Res 1999, 90:255-26I.

19. Riman T, Dickman PW, Nilsson S, Correia N, Nordlinder H, Magnusson CM, Persson IR: Risk factors for epithelial borderline ovarian tumors: results of a Swedish case-control study. Gynecol Oncol 200I, 83:575-585.

20. Purdie DM, Bain C], Webb PM, Whiteman DC, Pirozzo S, Green AC: Body size and ovarian cancer: case-control study and systematic review (Australia). Cancer Causes Control 200I, I 2:855-863.
21. Calle EE, Rodriguez C, Walker-Thurmond K, Thun MJ: Overweight, obesity, and mortality from cancer in a prospectively studied cohort of U.S. adults. N Engl J Med 2003, 348: I625-I638.

22. Farrow DC, Weiss NS, Lyon JL, Daling JR: Association of obesity and ovarian cancer in a case-control study. Am J Epidemiol 1989, 1 29:1300-1304.

23. Lubin F, Chetrit A, Freedman LS, Alfandary E, Fishler Y, Nitzan H, Zul$\tan A$, Modan B: Body mass index at age 18 years and during adult life and ovarian cancer risk. Am J Epidemiol 2003, I57:1 I3-120.

24. Engeland A, Tretli S, Bjorge T: Height, body mass index, and ovarian cancer: a follow-up of I.I million Norwegian women. J Natl Cancer Inst 2003, 95: I 244-I 248.

25. Dal Maso L, Franceschi S, Negri E, Conti E, Montella M, Vaccarella S, Canzonieri V, Parazzini F, La Vecchia C: Body size indices at different ages and epithelial ovarian cancer risk. Eur J Cancer 2002, 38: $1769-1774$.

26. Fairfield KM, Willett WC, Rosner BA, Manson JE, Speizer FE, Hankinson SE: Obesity, weight gain, and ovarian cancer. Obstet Gynecol 2002, I 00:288-296.

27. Kuper H, Cramer DW, Titus-Ernstoff L: Risk of ovarian cancer in the United States in relation to anthropometric measures: does the association depend on menopausal status? Cancer Causes Control 2002, I3:455-463.

28. Wolk A, Gridley G, Svensson M, Nyren O, McLaughlin JK, Fraumeni JF, Adam HO: A prospective study of obesity and cancer risk (Sweden). Cancer Causes Control 200I, I 2:13-2I.

29. Moller $\mathrm{H}$, Mellemgaard A, Lindvig K, Olsen JH: Obesity and cancer risk: a Danish record-linkage study. Eur J Cancer 1994, 30A:344-350.

30. Slattery ML, Schuman KL, West DW, French TK, Robison LM: Nutrient intake and ovarian cancer. Am J Epidemiol 1989, I30:497-502.

31. Anderson JP, Ross JA, Folsom AR: Anthropometric variables, physical activity, and incidence of ovarian cancer: The lowa Women's Health Study. Cancer 2004, 100:I515-I52I.

32. Lukanova A, Toniolo P, Lundin E, Micheli A, Akhmedkhanov A, Muti $P$, Zeleniuch-Jacquotte A, Biessy C, Lenner P, Krogh V, Berrino F, Hallmans G, Riboli E, Kaaks R: Body mass index in relation to ovarian cancer: a multi-centre nested case-control study. Int J Cancer 2002, 99:603-608.

33. Beehler GP, Sekhon M, Baker JA, Teter BE, McCann SE, Rodabaugh $\mathrm{KJ}$, Moysich KB: Risk of ovarian cancer associated with BMI varies by menopausal status. J Nutr 2006, I 36:288|-2886.

34. Greer JB, Modugno F, Ness RB, Allen GO: Anthropometry and the risk of epithelial ovarian cancer. Cancer 2006, 1 06:2247-2257.

35. Delort L, Kwiatkowski F, Chalabi N, Satih S, Bignon YJ, Bernard-Gallon DJ: Risk factors for early age at breast cancer onset--the "COSA program" population-based study. Anticancer Res 2007, 27:1087-1094.

36. Zhang L, Zhang Z, Yan W: Single nucleotide polymorphisms for DNA repair genes in breast cancer patients. Clin Chim Acta 2005, 359:150-I55.

37. Livak KJ: Allelic discrimination using fluorogenic probes and the 5 ' nuclease assay. Genet Anal 1999, I4: 143-I49.

38. Kwiatkowski F, Girard M, Hacène K, Berlie J: Sem: a suitable statistical software adaptated for research in oncology. Bull Cancer 2000, 87:715-72I. 